\title{
Marine long-term biodiversity assessment suggests loss of rare species in the Skagerrak and Kattegat region
}

\author{
Matthias Obst $^{1}$ (D) Saverio Vicario ${ }^{2} \cdot$ Kennet Lundin $^{3} \cdot$ Matz Berggren $^{1}$ • \\ Anna Karlsson ${ }^{4} \cdot$ Robert Haines $^{5} \cdot$ Alan Williams $^{5} \cdot$ Carole Goble $^{5} \cdot$ Cherian Mathew $^{6}$. \\ Anton Güntsch ${ }^{6}$
}

Received: 13 October 2016 /Revised: 4 April 2017 / Accepted: 6 June 2017 / Published online: 24 June 2017

(C) The Author(s) 2017. This article is an open access publication

\begin{abstract}
Studies of cumulative and long-term effects of human activities in the ocean are essential for developing realistic conservation targets. Here, we report the results of a recent national marine biodiversity inventory along the Swedish West coast between 2004 and 2009. The expedition revisited many historical localities that have been sampled with the same methods in the early twentieth century. We generated comparable datasets from our own investigation and the historical data to compare species richness, abundance, and geographic distribution of diversity. Our analysis indicates that the benthic ecosystems in the region have lost a large part of its original species richness over the last seven decades. We find evidence that especially rare species have disappeared. This process has caused a more homogenized community
\end{abstract}

Communicated by D. M. Paterson

Electronic supplementary material The online version of this article (doi:10.1007/s12526-017-0749-5) contains supplementary material, which is available to authorized users.

Matthias Obst

matthias.obst@marine.gu.se

1 Department of Marine Sciences and Gothenburg Global Biodiversity Centre, University of Gothenburg, Gothenburg, Sweden

2 Institute of Atmospheric Pollution Research, National Research Council, C/O Physics Department, University of Bari "Aldo Moro", Bari, Italy

3 Gothenburg Natural History Museum, Gothenburg, Sweden

4 Swedish Agency for Marine and Water Management, Gothenburg, Sweden

5 School of Computer Science, University of Manchester, Manchester, UK

6 Botanic Garden and Botanical Museum Berlin-Dahlem, Freie Universität Berlin, Berlin, Germany structure in the region and diminished historical biodiversity hotspots. We argue that the contemporary lack of rare species in the benthic ecosystems of the Kattegat and Skagerrak offers less opportunity to respond to environmental perturbations in the future and suggest improving the poor representation of rare species in the region. The study shows the value of biodiversity inventories as well as natural history collections in investigations of accumulated effects of anthropogenic activities and for re-establishing species-rich, productive, and resilient ecosystems.

Keywords Benthic $\cdot$ Marine conservation $\cdot$ Shifting baselines $\cdot$ Biodiversity inventory $\cdot$ North East Atlantic

\section{Introduction}

Marine habitats experience rapid declines in biodiversity worldwide (Jackson et al. 2001; Halpern et al. 2008), a process that creates urgent demand for a better understanding of the long-term effects of such severe alterations in ecosystem diversity (Rockström et al. 2009; Lotze 2010). Over the past decades, the impacts of major anthropogenic pressures on coastal and benthic marine biodiversity have been studied intensely. Here, especially field assessments investigated the negative effects arising from bottom trawling (Jennings and Kaiser 1998; Kaiser et al. 2006; Tillin et al. 2006; Worm et al. 2006; Olsgard et al. 2008), coastal nutrient loading (Rosenberg and Nilsson 2005; Quijon et al. 2008), and climate change (Norderhaug et al. 2015). However, since many of these drivers act on the ecosystems simultaneously and over long periods of time (Lotze et al. 2006; Halpern et al. 2008), it is difficult to infer cumulative impacts from such assessments (Moksnes et al. 2008; Robinson and Frid 2008). Furthermore, in many experimental field studies, the impacts are already a 
part of the control (Pauly 1995), and hence it is not possible to rely on contemporary and experimental investigations alone when examining long-term changes in marine ecosystems.

Historical studies can offer valuable insight in ecosystemwide responses to the overall sum of human pressures that act in concert and over long periods of time. For such investigations the benthos around the region of the North Sea is especially well suited. Compared to most coastal regions of the world, this area has a long history of biological recording with quantitative surveys dating back to the late nineteenth and early twentieth century (Petersen 1918; Robinson and Frid 2008; Narayanaswamy et al. 2010). Based on this information, a large number of historical comparisons have already been carried out. For example, long-term investigations of fish, plankton, and benthos in the Western English channel found indications for regime shifts during the last century caused by fishing pressures (Southward et al. 2005). Other studies investigated the Southern and central parts of the North Sea and found similar evidence for long-term changes in benthic community structure attributed to fishing (Pennington et al. 1998; Rumohr and Kujawski 2000; Bradshaw et al. 2002; Robinson and Frid 2008) and nutrient loading (Schroeder 2005; Schumacher et al. 2014). Likewise, a series of historical studies from the eastern parts of the North Sea documented remarkable long-term changes in benthic communities attributed to trawling pressure and eutrophication (Rosenberg and Möller 1979; Pearson et al. 1985; Rosenberg et al. 1987; Göransson 2002). Such assessments allow valuable insight into long-term transformation of ecosystems and may help to identify important biodiversity trends in a region, a feature highly relevant for future conservation policies (Pereira et al. 2013).

During the early twentieth century, an expedition led by L.A. Jägerskiöld inventoried the benthic diversity of the Kattegat and Skagerrak region (Jägerskiöld 1971). We were able to revisit many of these historical locations during a recent national marine biodiversity inventory program, and we used this opportunity to test the validity of historical data for understanding the long-term trends in biodiversity in this region. Our expedition re-sampled a large number of historical locations with similar equipment and methods, and we subsequently generated comparable datasets from both expeditions to analyse ecosystem-wide changes in species diversity over a period of more than 70 years.

\section{Materials and methods}

\section{Data collection}

The historical inventory was carried out in the Swedish, Danish, and Norwegian Economic Zone by L.A. Jägerskiöld in 1921-1938 (Jägerskiöld 1971). Overall, 440 benthic localities were visited in the Kattegat and Skagerrak, from shallow to deep water, and typically between spring and autumn (Fig. 1a), generating a dataset with 33,661 species observations. Usually, several samples were taken per locality by combining various dredges and trawls (Tables 1 and 2). Organisms that were obviously picked up in the water column were discarded. All living marine invertebrate species larger than $1 \mathrm{~mm}$ were collected, identified, preserved, and stored (fixed in formaldehyde, ethanol, or formol, and later transferred to ethanol). Subsequently, all specimens were vouchered, catalogued, reexamined by experts if necessary, and finally stored at the Gothenburg Natural History Museum, Sweden.

Our recent inventory revisited the historical locations between 2004 and 2009 (Fig. 1a). Here, altogether 504 localities were sampled during spring and autumn, generating a dataset with 17,249 species observation records. The equipment used was of the same type and with similar dimensions and mesh size as applied in the historical inventory (Tables 1 and 2). The same criteria for collection and identification were applied as in the historical inventory, while all material was stored in ethanol at the Gothenburg Natural History Museum, Sweden.

We prepared and submitted all original data from our own inventories as well as from the museum collections (Fig. 1a) including overall 50,910 species records to the Swedish Environmental and Climate Data Repository (www.ecds.se) under the identifier 01d148f8-f87c-47e3-adfc-c10619f6e9a1 (metadata) and http://webdav.swestore.se/snic/ecds/prod/ BenthicInventories/ (data file).
Fig. 1 Overview of analysed datasets. (a) Localities in the historical (red) and recent (blue) inventories; (b) Selected localities in the refined dataset used for statistical analysis
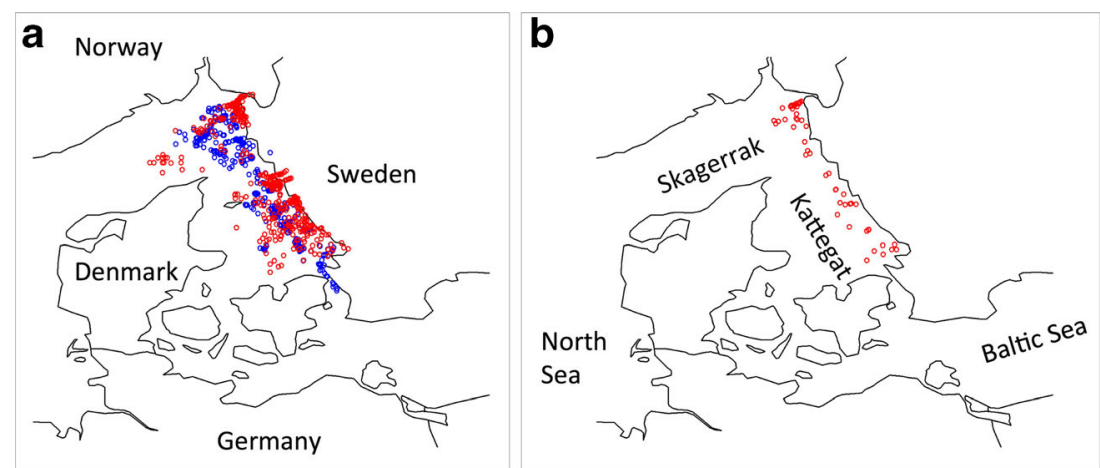
Table 1 Specifications of the sampling gear used in the historical and recent inventory

\begin{tabular}{llll}
\hline Inventory & Equipment code & Equipment type and dimension & Catchment area $\left(\mathrm{m}^{2}\right)$ \\
\hline Historical & Agas-100 & Agassiz trawl $100 \times 50 \mathrm{~cm}$ & 0.500 \\
Historical & Agas-75 & Small Agassiz $75 \times 40 \mathrm{~cm}$ & 0.300 \\
Historical & Ring-100 & Large ring dredge $100 \mathrm{~cm}$ (diameter) & 0.790 \\
Historical & Ring-58 & Small ring dredge $58 \mathrm{~cm}$ (diameter) & 0.265 \\
Historical & Tri-60 & Triangular dredge $60 \mathrm{~cm}$ & 0.156 \\
Historical & Rect-75 & Rectangular dredge $75 \times 20 \mathrm{~cm}$ & 0.150 \\
Recent & Agas-80 & Agassiz trawl $80 \times 50 \mathrm{~cm}$ & 0.400 \\
Recent & Ring-70 & Ring dredge $70 \mathrm{~cm}($ diameter) & 0.385 \\
Recent & Rock-80 & Rock dredge $80 \times 20 \mathrm{~cm}$ & 0.160 \\
Recent & Rock-40 & Rock dredge scraper $40 \times 20 \mathrm{~cm}$ & 0.080 \\
Recent & War-60 & Warén sledge $60 \times 15 \mathrm{~cm}$ & 0.090 \\
\hline
\end{tabular}

\section{Data cleaning, refinement, and taxonomic name resolution}

We employed a semi-automated workflow developed by Mathew et al. (2014) to generate comparable datasets from the metadata of both inventory programs. The workflow provides a user interface for preparation of taxonomically accurate species lists and observational records and can be executed online (https://portal.biovel.eu/workflows/641). All locations were assigned to the following habitat categories: soft bottom (sand, mud), hard bottom (rocks, boulders, stones), or shell gravel. We then structured species occurrences and sample locations according to habitat, geographical reference, sampling gear, and depth profile. Revisited and comparable samples were defined as locations with similar geographical reference up to the first decimal of both latitude and longitude. Locations also had to have overlapping or adjacent depth profiles, while all locations above the halocline (app. $15 \mathrm{~m}$ ) were excluded because the research vessels could not adequately sample such shallow habitats. Based on these criteria we selected a group of 54 revisited and comparable localities in the Swedish Exclusive Economic Zone (Fig. 1b, Table 2).

Sample effort was calculated as overall haul volume from the dimensions of the individual sample equipment and the haul length at each location (Tables 1 and 2). For the historical samples, this information was derived from the original logbooks of the Jägerskiöld inventory available at the Gothenburg Natural History Museum, Sweden.

Species observations from selected localities were cleaned and refined in the following order. We only included taxa unambiguously identified by taxonomic experts in both inventories, but excluded endoparasites. Spelling errors and variations in species names were identified and corrected with the taxonomic 'cluster' function of the workflow (Mathew et al. 2014). A few ambiguous entries such as missing species epithet (only listed as $s p$.), records with genus names only, or entries with 'cf' references were either resolved or excluded. All species names were transformed to the accepted name provided by the web services of Catalogue of Life (Roskov et al. 2014) and World Register of Marine Species (WoRMS) to eliminate all synonymies in the dataset (Mathew et al. 2014). Multiple records of the same species in a location were removed, leaving only presence information for further analysis in the data set. The resulting dataset (shown in Fig. 1b, available as supplementary online material File S1) was then used for the statistical analysis.

\section{Statistical analysis}

The variation between the samples was explored to identify and correct for any potential sampling bias in the historical and recent inventories. Variables included in the analysis were species richness, sampling effort, habitat, geographic location, depth, and season. First, we plotted the frequency distribution of mismatches in sampling effort, average sampling depth, sampling date, and substrate type for all revisited localities (Fig. 2). Second, we performed multidimensional scaling of all samples to visualize the similarity in species composition among and between localities of the two inventories (Fig. 3). Finally, we log transformed species richness and sampling effort (as advised by a preliminary Box-Cox analysis) and evaluated the variables using a generalized additive model (GAM) with bi-dimensional smothers, taking the dishomogeneity in the sampling effort into account (Zuur et al. 2009). Altogether, 703 models (160 of which included a biodiversity hotspot variable defined after exploratory analysis) were tested to compare the effect of the different variables on the variance in the data set (Fig. S1, Table S1-S3).

Species richness (number of species) was calculated as a function of sample effort (haul volume). In addition, we applied a classical rarefaction analysis, re-sampling the observations and the localities to assess significance and the species richness abundance-based coverage estimator (ACE) for each inventory. We used a non-parametric species richness 


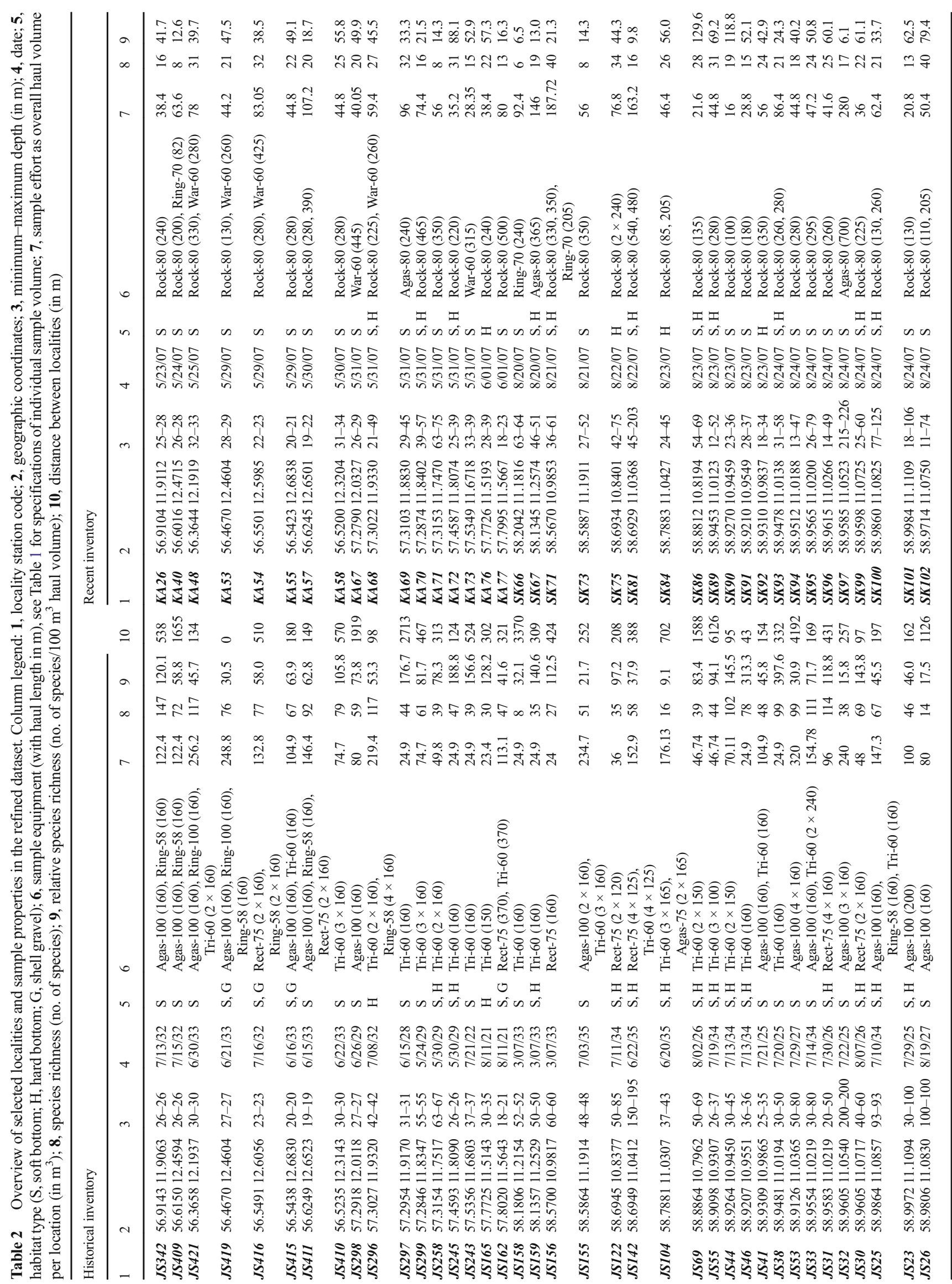




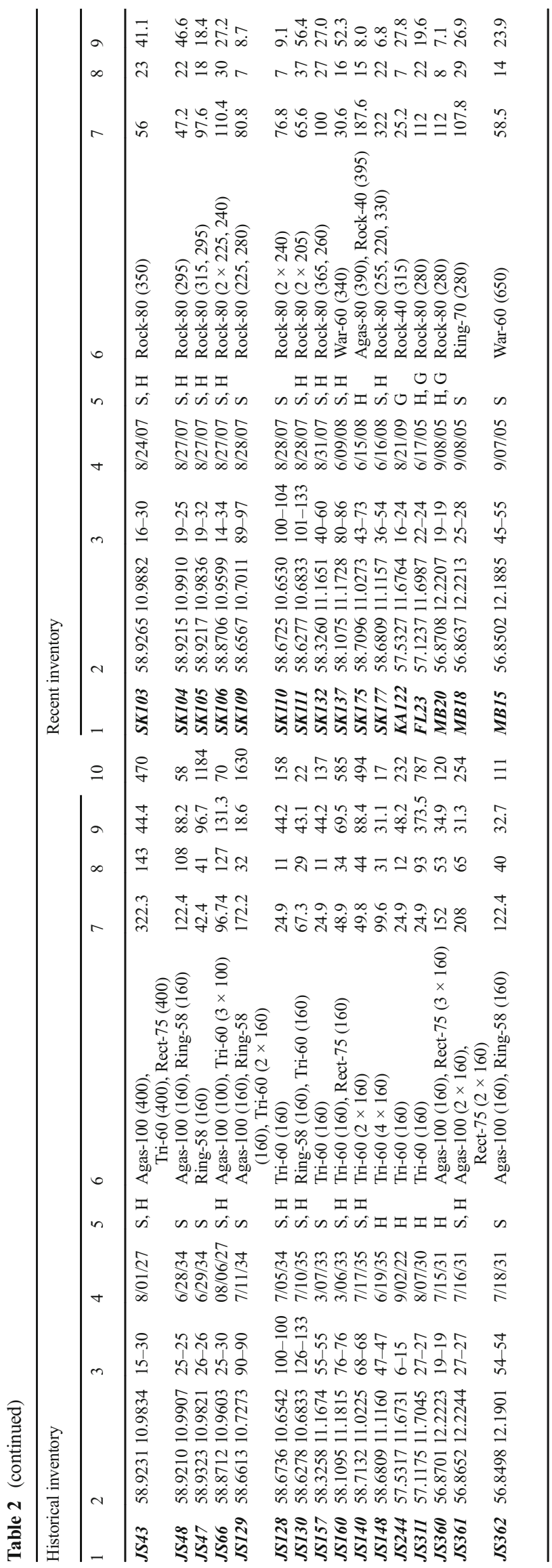

estimator (ACE-1) as advised in Gotelli and Colwell (2011) to obtain a quantitative estimate of species richness for repeated incidence data. Analyses were implemented with R scripts (Wang 2011; R Core Team 2013).

Species abundance was calculated as the relative frequency of occurrence for individual species in the selected 54 locations. We defined abundance thresholds at $10 \%$ of the total number of locations for rare species and at $50 \%$ for common species. This allowed us to classify all species into four abundances classes: absent $(0 \%)$, rare $(0 \%-<10 \%)$, intermediate (10-50\%), and common (>50\%).

Geographical structure was assessed by comparing the marginal values of the Akaike information criterion weight (wAIC) across 543 generalized additive models resulting from the different parameterisations of the geographical information, including spatial smothers (Table S1). Subsequently, the geographical structure was modelled with groupings of historical hotspots for a total of 160 models (Table S2). Historical hotspots were defined as the locations with the highest species richness in the historical data set, and included 16 localities with an average richness of 103 species $/ 100 \mathrm{~m}^{3}$ haul volume. The analysis was done with $\mathrm{R}$ scripts (Wood 2006; Rhodes et al. 2009; R Core Team 2013).

\section{Results}

\section{Exploration of variance}

Variation in sample effort was considerable (Figs. 2a, 4b, Table 2), both within and between inventories (historical/recent effort minimum $=23 / 16 \mathrm{~m}^{3}$, maximum $=322 / 322 \mathrm{~m}^{3}$, average $=104 / 78 \mathrm{~m}^{3}$, standard deviation $=80 / 60 \mathrm{~m}^{3}$ ). Most of the revisited localities had a mismatch in sampling effort between 20 and $100 \mathrm{~m}^{3}$ (Fig. 2a). Depth profiles only had substantial variation within each inventory, but not between inventories (histori$\mathrm{cal} /$ recent depth minimum $=11 / 19 \mathrm{~m}$, maximum $=200 / 220 \mathrm{~m}$, average $=51 / 47 \mathrm{~m}$, standard deviation $=36 / 35 \mathrm{~m}$ ). Most of the revisited localities showed mismatches in depth of $\pm 15 \mathrm{~m}$ (Fig. $2 b)$. The seasonal variation within and between inventories was confined to the summer months. Historical locations were sampled mostly between June and August, while most of the recent localities were sampled either in May or in August, resulting in a seasonal mismatch between the revisited localities of up to 3 months (Fig. 2c). The variation in the substrate between historical and recent localities was very small. Most localities consisted of either soft bottom or mixed soft and hard bottoms at both times of sampling (Figs. 2d and 3). Overall, there was no bias in the data sets that indicates systematic over- or under-sampling of a certain habitat, season, depth, effort, or sample gear in one of the two inventories (Figs. 2 and 3) and localities are comparable with regard to these variables. The variation in sampling effort, however, needs to be included when comparing species richness. 
Fig. 2 Variation in sampling conditions between historical and recent localities. Diagrams show the frequency distribution of mismatches in (a) sampling effort, (b) average sampling depth, and (c) sampling date. Diagram (d) shows mismatches in substrate type, where the size of circles corresponds to the number of revisited localities that change from one substrate to another. S, soft bottom; H, hard bottom; G, shell gravel; NA, information missing
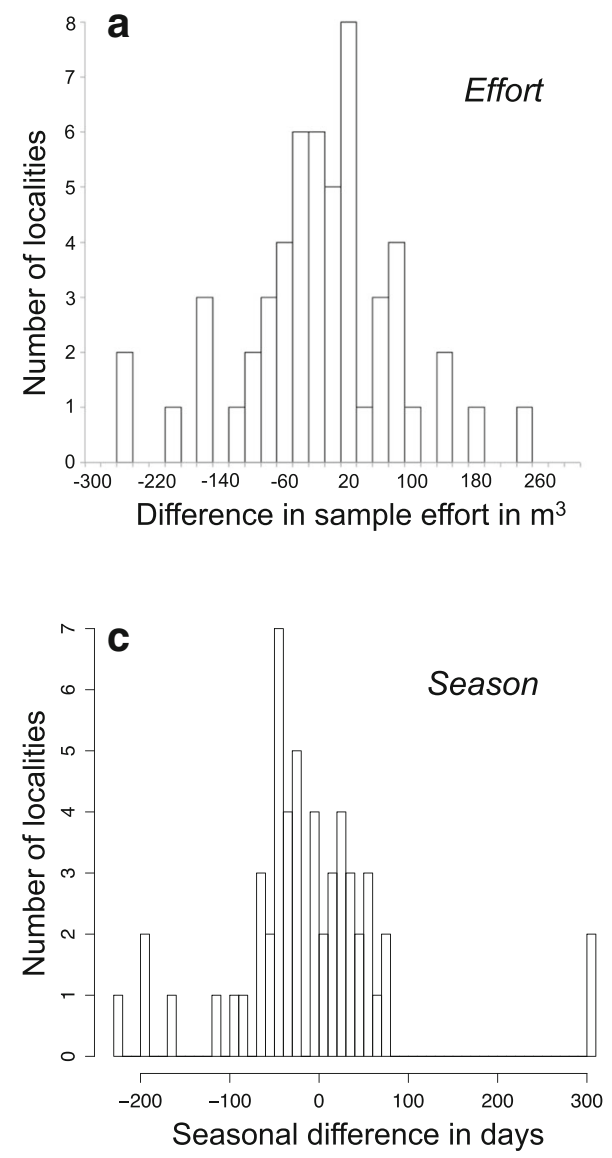
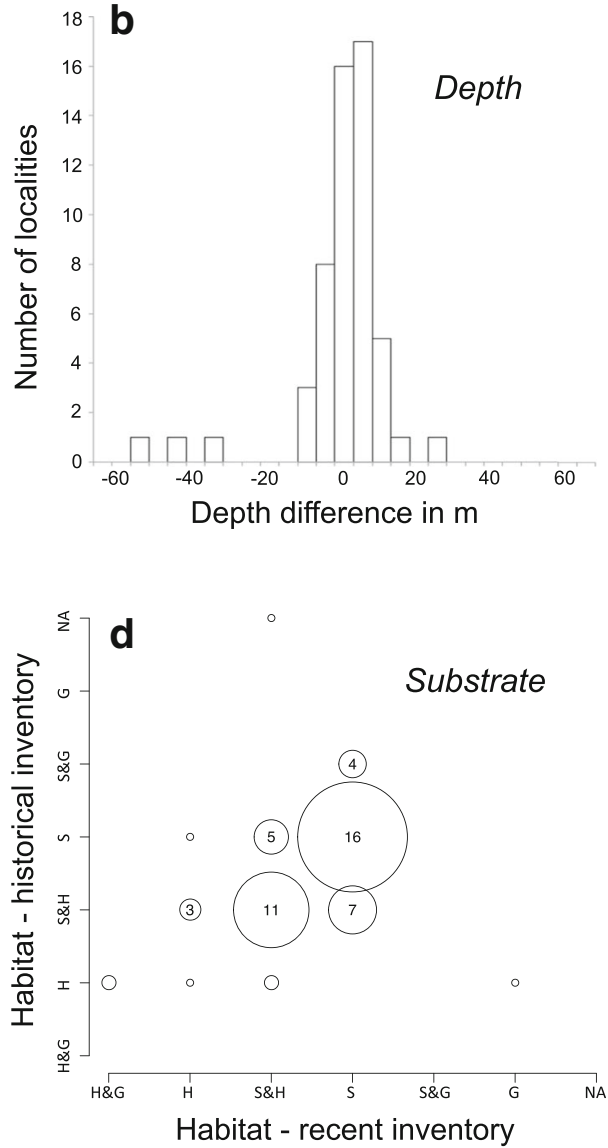

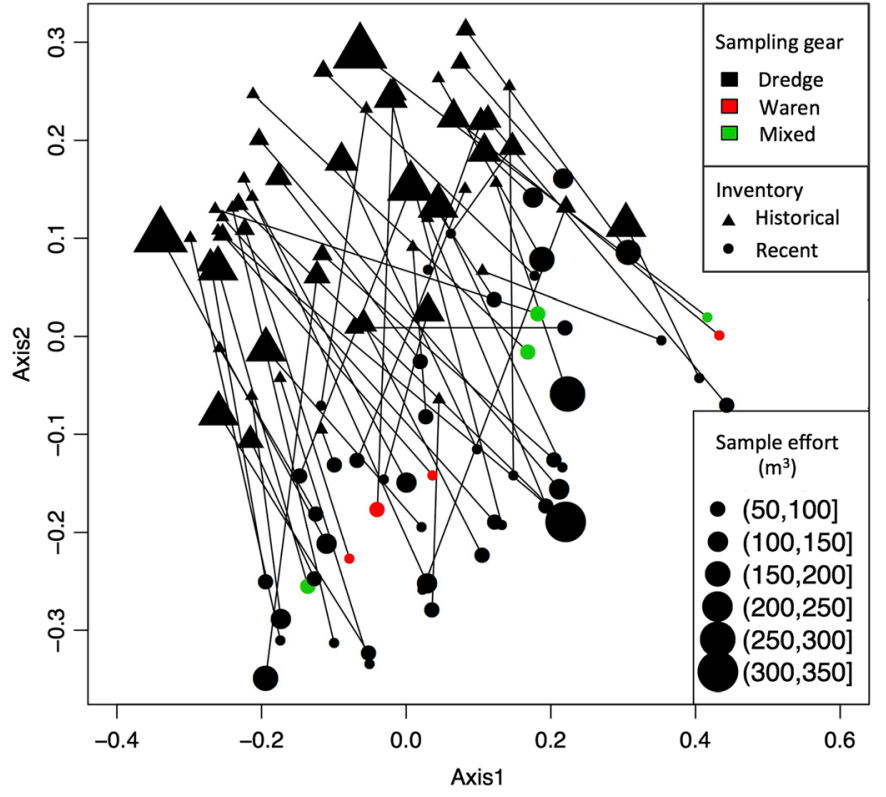

Fig. 3 Multidimensional scaling of the 108 sampling events (54 locations visited in the recent and historical inventory) using the Jaccard distance matrix. The same graph is shown twice to illustrate the covariates of the sampling events. Revisited localities are connected by a solid line.

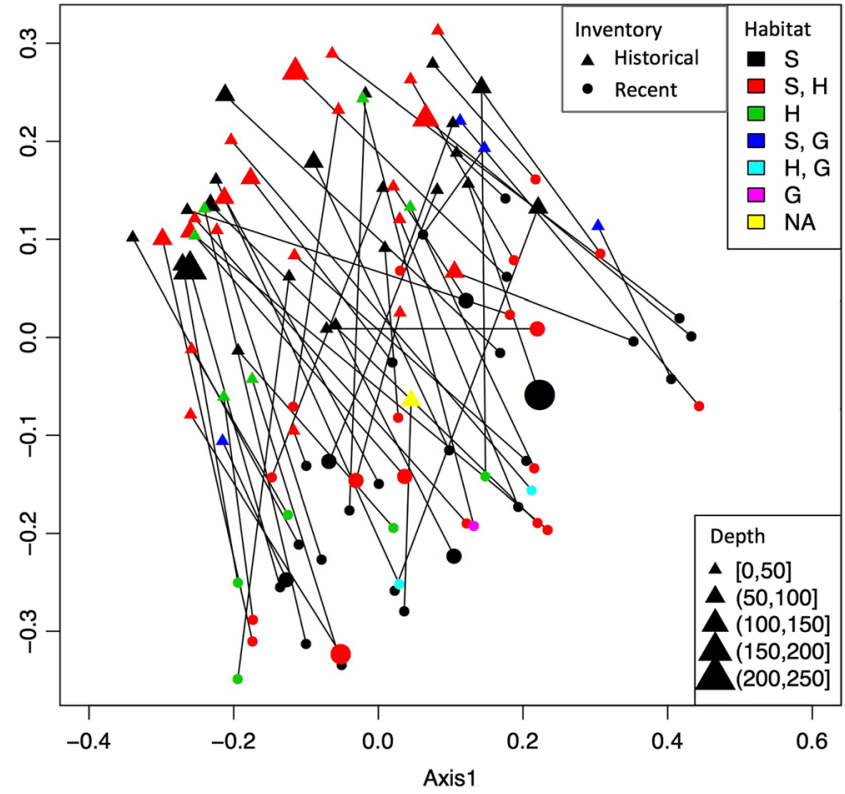

Habitat: S, soft bottom; H, hard bottom; G, shell gravel, and combinations thereof. Sampling gear: dredge (Agazziz trawls and dredges), Waren (Warén sledge), and mixed (combinations of the previous types) refer to the sample equipment in Table 1. Depth (average depth) 
The GAM approach attributed the variance to the habitat, biodiversity hotspots, sampling effort, and depth. Apart from depth, all variables had a different influence between the historical and recent inventory (Fig. S1, Table S3). In the historical inventory, $16.2 \%$ of the variance in species richness was assigned to sampling effort (significant at $P=0.00277$ ), while in the recent inventory, there was no relationship between species richness and sampling effort $(P=0.95)$. This indicates that the sampling in the historical inventory was still unsaturated (Fig. 4b, Table S3).

\section{Species richness}

The refined dataset included, overall, 648 species (4412 species records) across 54 revisited locations in the investigated region (Table 2). The historical partition included 607 species $(3282$ species records), while the recent partition included 254 species (1130 species records). Overall, $32.8 \%$ of the species were recovered across both inventories, while $60.8 \%$ occurred exclusively in the historical dataset, and $6.3 \%$ occurred only in the recent dataset.

The rarefaction curve indicated a halfway reduction of recent compared to historical species richness (Fig. 4a), which was confirmed by the ACE-1 estimator (Chao and Lee 1992) showing that the overall estimated species richness in the recent data set decreased to $47.2 \%$ of the historical values (Fig. 5). On average, historical localities recovered 88.2 species $/ 100 \mathrm{~m}^{3}$ haul volume, while recent localities recovered only 38.6 species $/ 100 \mathrm{~m}^{3}$ haul volume (Table 2 ). Also, the relations between species richness and sample effort were different between the historical and recent data set. Increasing

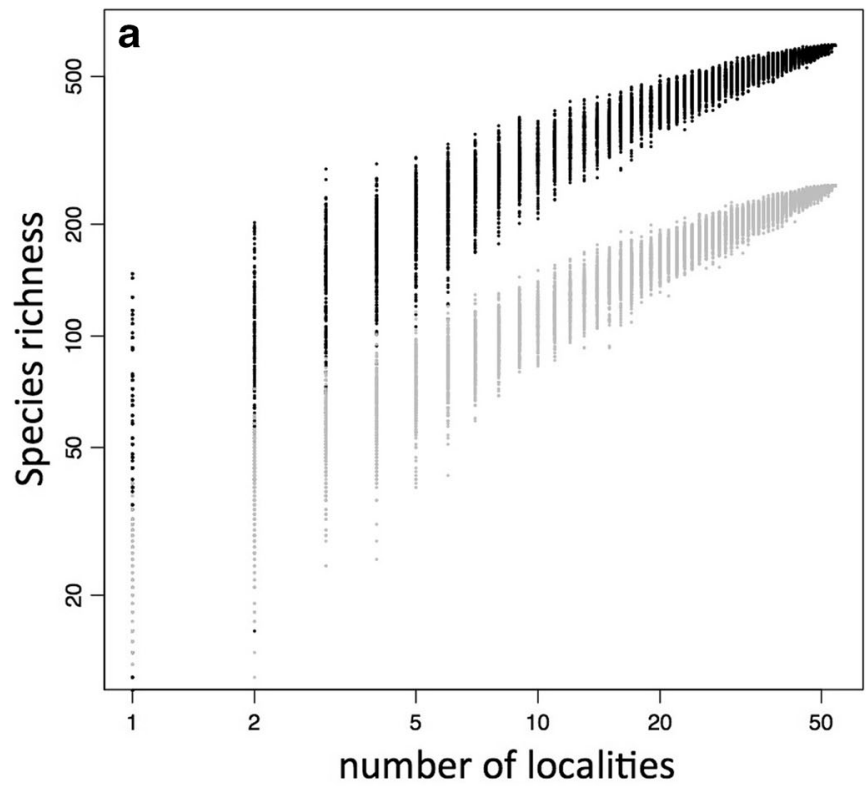

Fig. 4 Species richness in historical and recent inventories. Diagram (a) shows the rarefaction curve for overall species richness as a function of number of localities for the historical (black) and recent (grey) data set, using a logarithmic scale. The graph is based on 100 permutations for

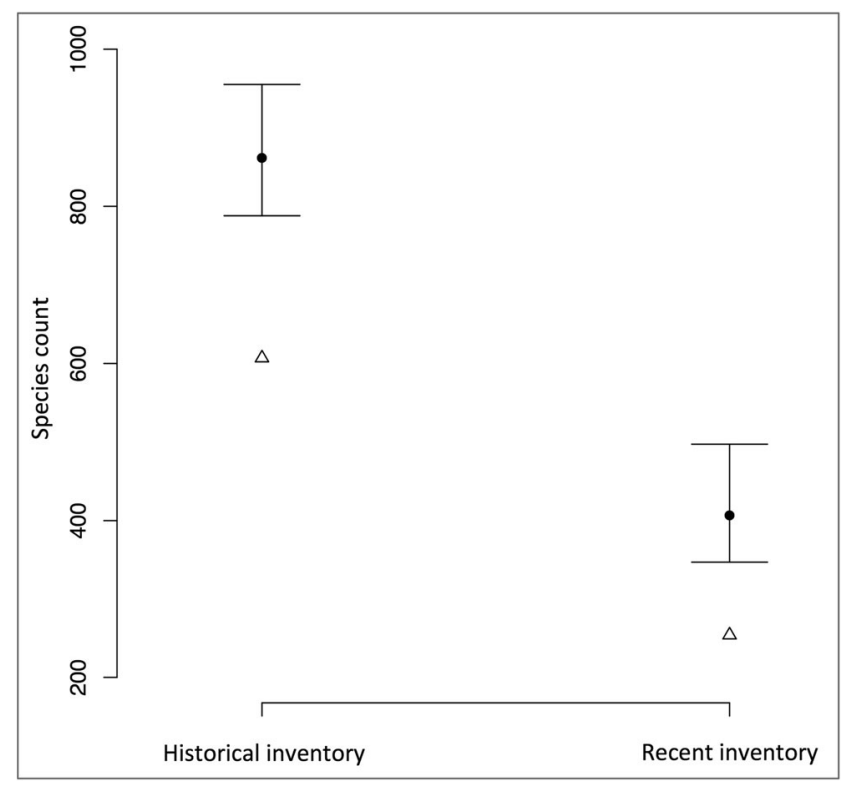

Fig. 5 Diagram showing observed (triangles) and estimated (dots) values calculated by the ACE-1 estimator of species richness. Upper and lower bounds are indicated by the whiskers

effort resulted in higher species richness in historical samples, but this was not the case in recent samples (Fig. 4b).

\section{Abundance trends}

The comparison of abundances between the historical and recent data sets showed a predominating negative trend (Fig. 6, Table 3). Overall, $74.7 \%$ of the investigated species

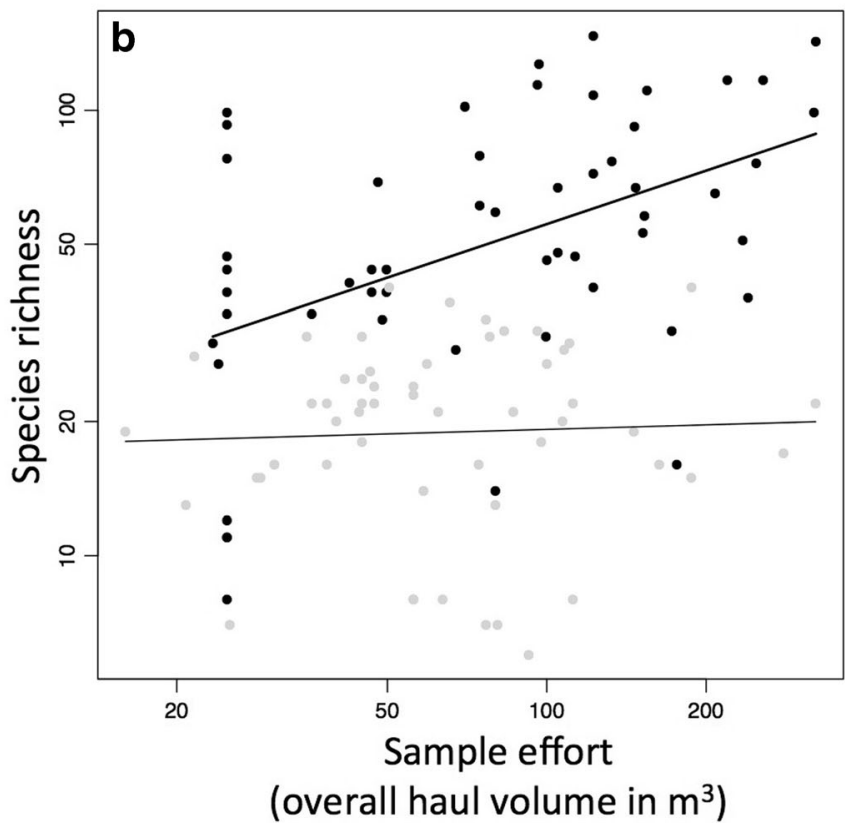

sampling size plotted. Diagram (b) shows species richness (number of species) over sampling effort (overall haul volume) at individual locations. Historical samples are shown with black circles and a bold trend line. Recent samples are shown with grey circles and a regular trend line 


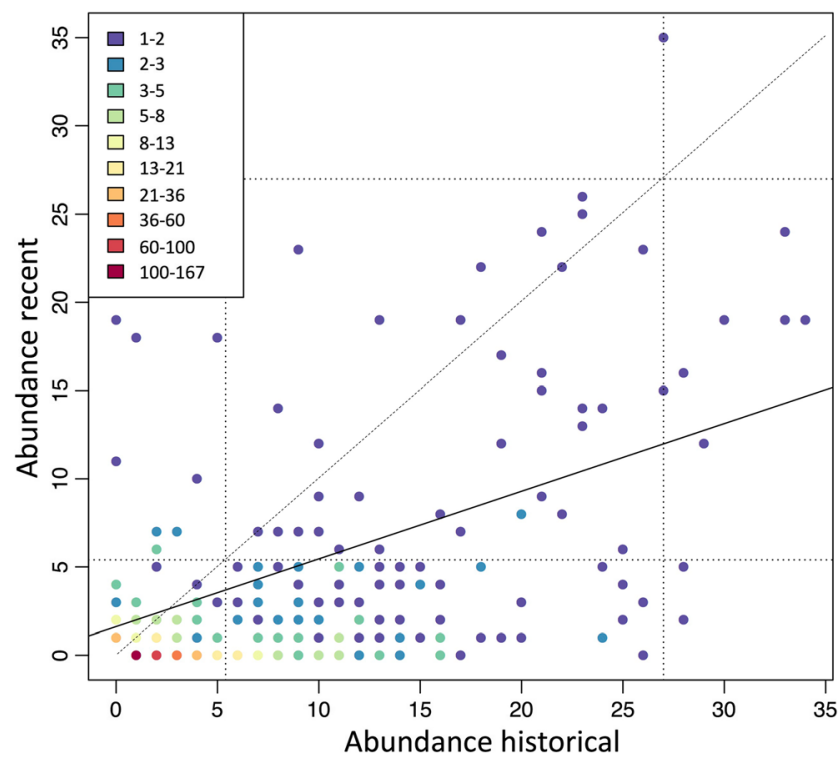

Fig. 6 Temporal changes in species abundance. The diagram shows a plot of abundance for 648 species in the historical (x-axis) and recent (yaxis) inventory. Abundance is measured as relative frequency of occurrence in the 54 locations. Colours indicate how many species have the same given pairs of counts (see legend within figure). The solid line is the trend line, while dotted lines indicate selected thresholds for rare species $(10 \%)$ and for common species $(50 \%)$. The dotted diagonal line indicates equal abundances across both inventories

showed decreasing abundances, changing either from rare to absent, intermediate to absent, intermediate to rare, common to rare, or common to intermediate. In contrast, only $7.8 \%$ of the species showed increasing abundances, changing from absent to rare, absent to intermediate, and rare to intermediate. Finally, $17.5 \%$ of the species remained in their historical abundance classes.
Among the species with strongest positive abundance trends, we found corals (Caryophyllia smithii, Kophobelemnon stelliferum, Alcyonium digitatum), bivalves (Nucula nitidosa N. nucleus, Mysia undata, Abra alba, Pecten maximus, Thracia convexa, Pododesmus patelliformis, Modiolarca subpicta), and one polychaete (Nephtys kersivalensis). These species are typically small- to mediumsized suspension or deposit feeders, living on top or within the sediment (epifauna, infauna). Among the species with the strongest negative abundance trends, we found especially polychaetes (Pectinaria auricoma, Goniada maculata, Aphrodita aculeata, Pista cristata, Owenia fusiformis), but also one echinoderm (Psammechinus miliaris), a crustacean (Verruca stroemia), and a mollusc (Buccinum undatum). These species are typically small- to medium-sized predators, scavengers or suspension feeders, living on top or within the sediment (epifauna, infauna).

\section{Geographic distribution of diversity}

The analysis of the historical samples across 160 GAM models with a biodiversity hotspot predictor rendered three areas with high biodiversity $(n=16)$ in the historical data set (Fig. 7). The northernmost area $(n=7)$ lies in the centre of a national marine sanctuary (Gonzalez-Mirelis et al. 2014), while the others are located on the shallow water banks $(n=3)$ and in the coastal zones $(n=6)$ between Denmark and Sweden. By grouping all 16 species rich localities together, we obtained a 95\% confidence set with 6 models, while the best model included $54 \%$ of the weight of the selected models (Table S2). The geographical structure is well described by the

Table 3 Changes in species abundances as indicated by the number (and percentage) of species classified in different abundances classes in the two surveys. Grey cells indicate species without changes in abundance trends. Species with increasing abundances are above the grey cells, while species with decreasing abundances are below

\section{Recent}

\begin{tabular}{c|cccc}
\cline { 2 - 5 } Historical & Absent & Rare & Intermediate & Common \\
\hline Absent & 0 & 39 & 2 & 0 \\
Rare & 336 & $(6.0 \%)$ & $(0.3 \%)$ & \\
& $(51.9 \%)$ & $(11.9 \%)$ & $(1.5 \%)$ & 0 \\
Intermediate & 58 & 83 & 33 & 0 \\
Common & $(9.0 \%)$ & $(12.8 \%)$ & $(5.1 \%)$ & \\
& 0 & 2 & 7 & 1 \\
& & $(0.3 \%)$ & $(1.1 \%)$ & $(0.1 \%)$
\end{tabular}




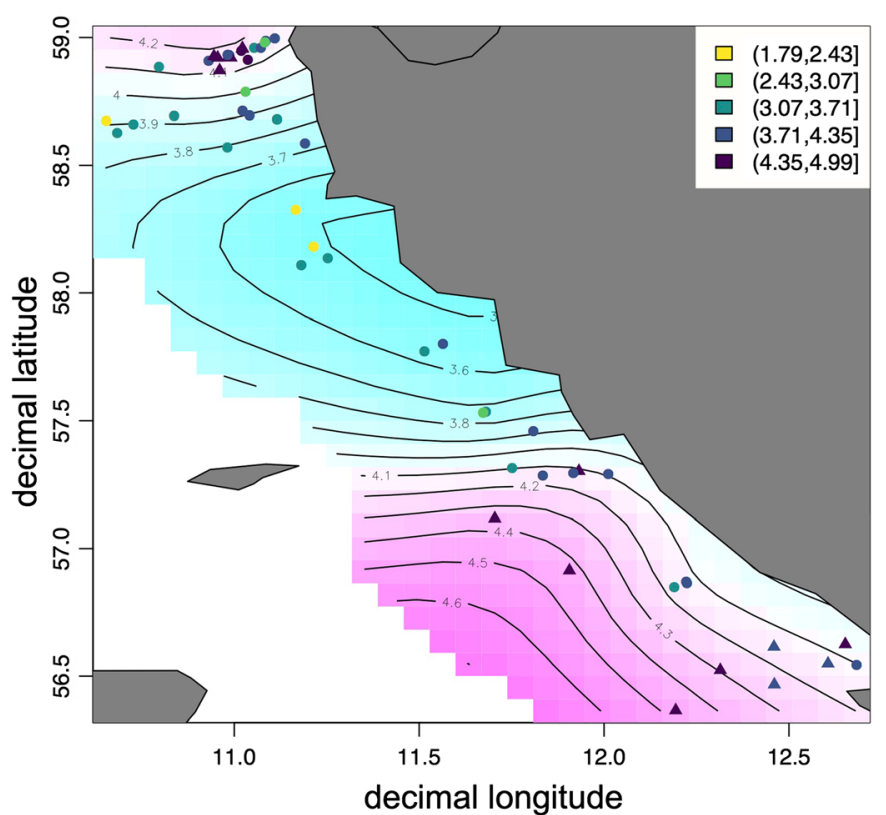

Fig. 7 Geographical distribution of species richness. Alpha diversity is mapped in the investigated area after smoothing with a generalized additive model for (a) the historical and (b) the recent dataset. Lines connect values indicating the log of the species richness, after correction for the non-geographic parameters and smoothing, while

hotspot-grouping variable (96\% of wAIC). This hotspot structure was strong in historical samples $(79.7 \%$ of variance of fitted values) but has faded in the recent samples $(9.2 \%$ of variance of fitted values), indicating that hotspots are less pronounced and species richness is more evenly distributed in the recent data set.

\section{Discussion}

\section{Sampling bias and working with inconsistent data sets}

Our study investigated the changes in richness, abundance, and geographic distribution of benthic species in the Kattegat and Skagerrak region based on the recordings made by two large biodiversity inventories. Although both inventories had a very similar design, the data generated by these investigations retained considerable heterogeneity. By using a carefully filtered subset of 54 revisited localities sampled with similar methods during the summer season, we could remove a large part of the heterogeneity. However, some variance in depth, season substrate, and constitution of the sample gear remained and may influence the observed patterns. However, we found no evidence of systematic bias in any of these variables across both inventories. Additional factors that may have influenced the historical changes observed in this study may be the coarse partitioning of the localities into three habitat types (hard bottom, soft bottom, and shell gravel), or the estimation of sample effort from the equipment's

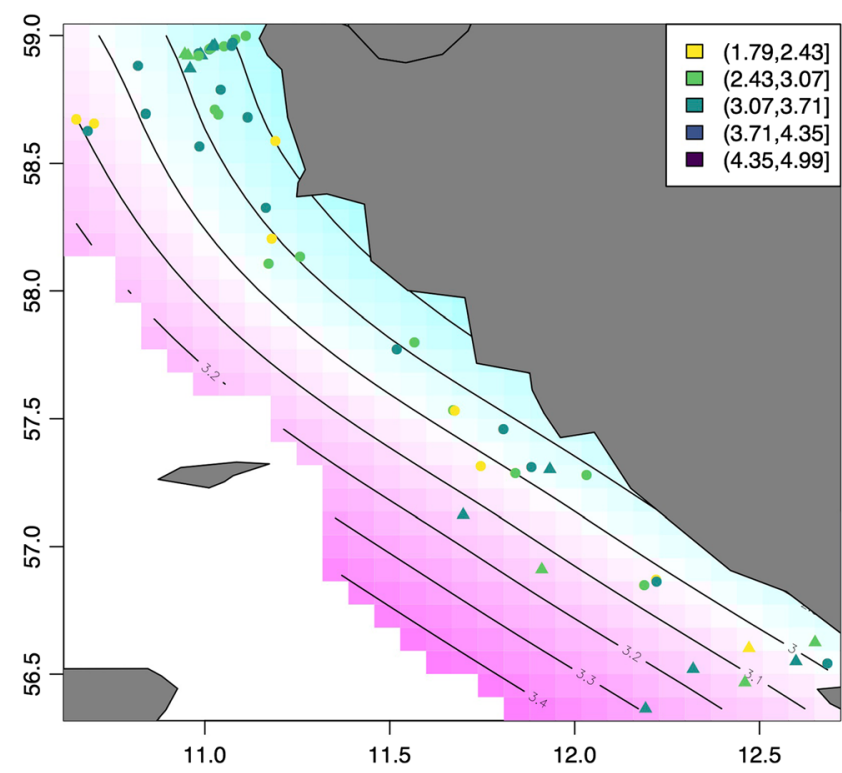

colours range from blue-green (low values) to purple (high values). Historical hotspots are indicted with triangles, while all other localities are indicated with circles. Results are shown without a confidence interval. Colour of localities indicates the log of the relative species richness (see legend within figure)

catchment area and the overall haul length. Also, the overall sampling period, which was longer for the historical data set (1921-35) than for the recent one (2004-09) may have captured more of the temporal species turnover and hence contributed to the higher levels of alpha diversity observed in the historical data. In conclusion, our results cannot entirely be assigned to the long-term changes in the region, and may to some extent be caused by the deviations between the sampling routines that we could not control. In this context, our objective was not to remove all sampling bias from the data, but attempt to find a trade-off between the degree of harmonization of the data sets and the conclusions that can be drawn from the analysis.

\section{Historical trends}

Our results indicate a reduction of species richness in the investigated region, which can be explained to some extent by the extirpation of rare species. The comparison of species abundances in the historical and recent inventory suggests that more than $50 \%$ of the recorded species change status from rare to absent. This trend seems to have contributed to a more homogenized community structure across the investigated region and may have diminished former biodiversity hotspots. Although the longer sampling period of the historical inventory may have increased the overall capture of rare species, it does not influence the species richness at the level of individual localities. Our results show that historical localities not only have a higher yield of species for a given sampling effort, 
but also a tendency to obtain more species with higher sampling effort. This is not the case in recent localities, where higher sampling effort does not yield more species. One of the explanations for these differences may be the absence of rare species in the recent localities.

A comparison with similar historical accounts shows that substantial regime shifts over longer time periods are known for the region (Rosenberg and Möller 1979; Robinson and Frid 2008). Our results show a $32 \%$ overlap in species assemblages between the historical and recent inventory, a figure that is very similar to estimates obtained by Pearson et al. (1985) and Rosenberg et al. (1987) over a similar period. However, in contrast to previous long-term studies, which report the species turnover as a balance between species recruitment and extirpation, our study also indicates a severe loss of alpha diversity in addition to the regime shift.

\section{Potential causes and consequences of species reduction}

A deeper analysis of ecological responses due to changes in the species composition is limited by the lack of consistent trait information for the majority of the species included in this study. However, some responses to prevalent pressures in the region may be discussed using representative species. Anthropogenic drivers that influence benthic diversity in the North Sea are typically associated with pollution, overfishing, habitat destruction, invasive species, and climate change (Lotze et al. 2006; Doney and Schimel 2007; Halpern et al. 2008). The reduction of alpha diversity observed in our study is likely to be related to a combination of these factors, but we have little indication of any specific causes for the observed loss in species richness. However, depletion of ecological niches through continuous physical disturbance (e.g. seabed trawling) is a well-documented process in the region, which is known to remove rare and specialist species from the ecosystem (Jennings and Kaiser 1998; Kaiser et al. 2006; Clavel et al. 2011). In addition, we observed that fragile infauna such as burrowing and tube-dwelling polychaetes were among the species with the strongest signals of decline, which may also be a response to continuous trawling activities. In contrast, more robust in- and epifauna like molluscs and corals seemed to have increased over time, and this pattern may be indicative for a better resistance of such species to physical disturbance. However, the observed changes in community composition are likely to be caused by a combination of several factors. Many of the species that have become more dominant are suspension and deposit feeders, organisms that benefit from the elevated nutrient levels in the region (Graneli and Sundback 1985; Posey et al. 1999; Karlson et al. 2002), while other important drivers of the observed changes in community composition may also include constantly rising sea temperatures and associated changes in water quality that can affect individual species differently (Hiddink et al. 2015). In conclusion, our study only includes two distant sampling periods, while specific environmental data associated with potential drivers of change were not available for analysis. Future inventories and monitoring programs should therefore emphasize the collection or linkage to environmental information to allow a deeper understanding of the impact of specific drivers on biodiversity decline.

The reduction of rare species indicated in our study may have implications on the resilience of the benthic ecosystems in the region. Specialist decline is known to cause functional homogenisation, which effects ecosystem functioning and productivity in the long-term and may ultimately lead to deterioration of important ecosystem services (Clavel et al. 2011; Cardinale et al. 2012). An increasing amount of studies shows that undisturbed marine ecosystems possess a broader functional reservoir allowing them to react better to environmental perturbations compared to exploited systems (Stachowicz et al. 2007; Rasher et al. 2013). Therefore, the constitution of rare species in the ecosystem should be better monitored in marine conservation programs. Appropriate indicators for biodiversity already exist as a part of national and international legislation (Borja 2006) and should be used to actively improve the representation of rare species in benthic assemblages. This intention could be realized by introducing new assessment methods into biodiversity monitoring programs, which enable a better accounting for rare species (Bourlat et al. 2013).

Acknowledgements We thank the staff at the Sven Lovén Center for Marine Sciences for all support during the cruises, and the Gothenburg Natural History Museum for processing the collected material and providing both new and historical collection data. We acknowledge the tremendous effort by the taxonomists who identified the collected species as a part of the Swedish Taxonomy Initiative. We also thank Lorna Morris for proof-reading the manuscript. This study is dedicated to Hans G. Hansson, a veteran of marine biodiversity. The marine inventories conducted between 2004 and 2009 were funded by the Swedish Taxonomy Initiative and the Swedish Environmental Protection Agency. The analysis was supported by the Swedish Research Council through the Swedish LifeWatch project (http://swedishlifewatch.se, grant no. 829-2009- 6278) and by the EU's Seventh Framework Program project BioVeL (www. biovel.eu, grant no. 283359).

Compliance with ethical standards This study complies with ethical standards, according to the rules and guidelines of thejournal.

Conflict of interest The authors declare that they have no conflict of interest.

Open Access This article is distributed under the terms of the Creative Commons Attribution 4.0 International License (http:// creativecommons.org/licenses/by/4.0/), which permits unrestricted use, distribution, and reproduction in any medium, provided you give appropriate credit to the original author(s) and the source, provide a link to the Creative Commons license, and indicate if changes were made. 


\section{References}

Borja A (2006) The new European marine strategy directive: difficulties, opportunities, and challenges. Mar Pollut Bull 52(3):239-242

Bourlat SJ, Borja A, Gilbert J, Taylor MI, Davies N, Weisberg SB, Griffith JF, Lettieri T, Field D, Benzie J, Gloeckner FO, Rodriguez-Ezpeleta N, Faith DP, Bean TP, Obst M (2013) Genomics in marine monitoring: new opportunities for assessing marine health status. Mar Pollut Bull 74(1):19-31

Bradshaw C, Veale LO, Brand AR (2002) The role of scallop-dredge disturbance in long-term changes in Irish Sea benthic communities: a re-analysis of an historical dataset. J Sea Res 47(2):161-184

Cardinale BJ, Duffy JE, Gonzalez A, Hooper DU, Perrings C, Venail P, Narwani A, Mace GM, Tilman D, Wardle DA, Kinzig AP, Daily GC, Loreau M, Grace JB, Larigauderie A, Srivastava DS, Naeem S (2012) Biodiversity loss and its impact on humanity. Nature 486(7401):59-67

Chao A, Lee SM (1992) Estimating the number of classes via sample coverage. J Am Stat Assoc 87(417):210-217

Clavel J, Julliard R, Devictor V (2011) Worldwide decline of specialist species: toward a global functional homogenization? Front Ecol Environ 9(4):222-228

Doney SC, Schimel DS (2007) Carbon and climate system coupling on timescales from the Precambrian to the anthropocene. Annu Rev Environ Resour 32:31-66

Gonzalez-Mirelis G, Lindegarth M, Sköld M (2014) Using vessel monitoring system data to improve systematic conservation planning of a multiple-use marine protected area, the Kosterhavet National Park (Sweden). Ambio 43(2):162-174

Göransson P (2002) Petersen's benthic macrofauna stations revisited in the Oresund area (southern Sweden) and species composition in the 1990s - signs of decreased biological variation. Sarsia 87(4):263280

Gotelli NJ, Colwell RK (2011) Estimating species richness. In: Magurran AE, McGill BJ (eds) Biological diversity: Frontiers in measuring biodiversity. Oxford University Press, New York, pp 39-54

Graneli E, Sundback K (1985) The response of planktonic and microbenthic algal assemblages to nutrient enrichment in shallow coastal waters, southwest Sweden. J Exp Mar Biol Ecol 85(3):253268

Halpern BS, Walbridge S, Selkoe KA, Kappel CV, Micheli F, D’Agrosa C, Bruno JF, Casey KS, Ebert C, Fox HE, Fujita R, Heinemann D, Lenihan HS, Madin EMP, Perry MT, Selig ER, Spalding M, Steneck R, Watson R (2008) A global map of human impact on marine ecosystems. Science 319(5865):948-952

Hiddink JG, Burrows MT, García Molinos J (2015) Temperature tracking by North Sea benthic invertebrates in response to climate change. Glob Chang Biol 21(1):117-129

Jackson JBC, Kirby MX, Berger WH, Bjorndal KA, Botsford LW, Bourque BJ, Bradbury RH, Cooke R, Erlandson J, Estes JA, Hughes TP, Kidwell S, Lange CB, Lenihan HS, Pandolfi JM, Peterson CH, Steneck RS, Tegner MJ, Warner RR (2001) Historical overfishing and the recent collapse of coastal ecosystems. Science 293(5530):629-638

Jägerskiöld LA (1971) A survey of the marine benthonic macro-fauna along the Swedish west coast 1921-1938. Acta Regia Societatis Scientiarum et Litterarum Gothoborgensis, Zoologica 6. Göteborg

Jennings S, Kaiser MJ (1998) The effects of fishing on marine ecosystems. In: Blaxter JHS, Southward AJ, Tyler PA (eds) Advances in marine biology, (Vol. 34). pp 201-212

Kaiser MJ, Clarke KR, Hinz H, Austen MCV, Somerfield PJ, Karakassis I (2006) Global analysis of response and recovery of benthic biota to fishing. Mar Ecol Prog Ser 311:1-14

Karlson K, Rosenberg R, Bonsdorff E (2002) Temporal and spatial largescale effects of eutrophication and oxygen deficiency on benthic fauna in Scandinavian and Baltic waters - a review. In: Gibson RN, Barnes M, Atkinson RJA (eds), Oceanography and marine biology: an annual review, (Vol 40). pp 427-489

Lotze HK (2010) Historical reconstruction of human-induced changes in US estuaries. In: Gibson RN, Atkinson RJA, Gordon JDM (eds) Oceanography and marine biology: an annual review, (Vol 48). pp 267-338

Lotze HK, Lenihan HS, Bourque BJ, Bradbury RH, Cooke RG, Kay MC, Kidwell SM, Kirby MX, Peterson CH, Jackson JBC (2006) Depletion, degradation, and recovery potential of estuaries and coastal seas. Science 312(5781):1806-1809

Mathew C, Güntsch A, Obst M, Vicario S, Haines R, Williams AR, de Jong Y, Goble C (2014) A semi-automated workflow for biodiversity data retrieval, cleaning, and quality control. Biodiv Data J 2: e4221. doi: 10.3897/BDJ.2.e4221

Moksnes P-O, Gullström M, Tryman K, Baden S (2008) Trophic cascades in a temperate seagrass community. Oikos 117(5):763-777

Narayanaswamy BE, Renaud PE, Duineveld GCA, Berge J, Lavaleye MSS, Reiss H, Brattegard T (2010) Biodiversity trends along the western European margin. PLoS One 5(12). doi:10.1371/journal. pone. 0014295

Norderhaug KM, Gundersen H, Pedersen A, Moy F, Green N, Walday MG, Gitmark JK, Ledang AB, Bjerkeng B, Hjermann D, Trannum HC (2015) Effects of climate and eutrophication on the diversity of hard bottom communities on the Skagerrak coast 1990-2010. Mar Ecol Prog Ser 530:29-46

Olsgard F, Schaanning MT, Widdicombe S, Kendall MA, Austen MC (2008) Effects of bottom trawling on ecosystem functioning. J Exp Mar Biol Ecol 366(1-2):123-133

Pauly D (1995) Anecdotes and the shifting base-line syndrome of fisheries. Trends Ecol Evol 10(10):430-430

Pearson TH, Josefson AB, Rosenberg R (1985) Petersen benthic stations revisited. 1. Is the Kattegatt becoming eutrophic? J Exp Mar Biol Ecol 92(2-3):157-206

Pennington D, Veale LO, Hartnoll RG (1998) Re-analysis of an historical benthic data set from the Irish Sea. Estuar Coast Shelf Sci 46(5): 769-776

Pereira HM, Ferrier S, Walters M, Geller GN, Jongman RHG, Scholes RJ, Bruford MW, Brummitt N, Butchart SHM, Cardoso AC, Coops NC, Dulloo E, Faith DP, Freyhof J, Gregory RD, Heip C, Hoft R, Hurtt G, Jetz W, Karp DS, McGeoch MA, Obura D, Onoda Y, Pettorelli N, Reyers B, Sayre R, Scharlemann JPW, Stuart SN, Turak E, Walpole M, Wegmann M (2013) Essential biodiversity variables. Science 339(6117):277-278

Petersen CGJ (1918) The sea bottom and its production of fish food. A survey of the work done in connection with the valuation of the Danish waters from 1883-1917. Rep Danish Biol Station 25: $1-62$

Posey MH, Alphin TD, Cahoon L, Lindquist D, Becker ME (1999) Interactive effects of nutrient additions and predation on infaunal communities. Estuaries 22(3B):785-792

Quijon PA, Kelly MC, Snelgrove PVR (2008) The role of sinking phytodetritus in structuring shallow-water benthic communities. J Exp Mar Biol Ecol 366(1-2):134-145

R Core Team (2013). R: A language and environment for statistical computing. R Foundation for Statistical Computing, Vienna, Austria. ISBN 3-900051-07-0. URL http://www.R-project.org/

Rasher DB, Hoey AS, Hay ME (2013) Consumer diversity interacts with prey defenses to drive ecosystem function. Ecology 94(6):13471358

Rhodes JR, McAlpin CA, Zuur AF, Smith GM, Ieno EN (2009) GLMM applied on the spatial distribution of koalas in a fragmented landscape. In: Zuur AF, Ieno EN, Walker N, Saveliev AA, Smith GM (eds) Mixed effects models and extensions in ecology with R. Springer, New York, pp 469-492 
Robinson LA, Frid CLJ (2008) Historical marine ecology: examining the role of fisheries in changes in North Sea benthos. Ambio 37(5):362 371

Rockström J, Steffen W, Noone K, Persson A, Chapin FS, Lambin EF, Lenton TM, Scheffer M, Folke C, Schellnhuber HJ, Nykvist B, de Wit CA, Hughes T, van der Leeuw S, Rodhe H, Sorlin S, Snyder PK, Costanza R, Svedin U, Falkenmark F, Karlberg L, Corell RW, Fabry VJ, Hansen J, Walker B, Liverman D, Richardson K, Crutzen P, Foley JA (2009) A safe operating space for humanity. Nature 461(7263):472-475

Rosenberg R, Möller P (1979) Salinity stratified benthic macrofaunal communities and long-term monitoring along the west-coast of Sweden. J Exp Mar Biol Ecol 37(2):175-203

Rosenberg R, Nilsson HC (2005) Deterioration of soft-bottom benthos along the Swedish Skagerrak coast. J Sea Res 54(3):231-242

Rosenberg R, Gray JS, Josefson AB, Pearson TH (1987) Petersen benthic stations revisited. 2. Is the Oslofjord and eastern Skagerrak enriched? J Exp Mar Biol Ecol 105(2-3):219-251

Roskov Y, Abucay L, Orrell T, Nicolson D, Kunze T, Culham A, Bailly N, Kirk P, Bourgoin T, DeWalt RE, Decock W, De Wever A (2014) Species 2000 \& ITIS catalogue of life. Digital resource at http:// www.catalogueoflife.org/col. Species 2000: Naturalis, Leiden, The Netherlands

Rumohr H, Kujawski T (2000) The impact of trawl fishery on the epifauna of the southern North Sea. ICES J Mar Sci 57(5): $1389-1394$

Schroeder A (2005) Community dynamics and development of soft bottom macrozoobenthos in the German Bight (North Sea) 1969-2000. Ber Polarforsch Meeresforsch 494. Dissertation: Alfred-WegenerInstitut für Polar- und Meeresforschung
Schumacher J, Dolch T, Reise K (2014) Transitions in sandflat biota since the 1930s: effects of sea-level rise, eutrophication and biological globalization in the tidal bay Konigshafen, northern Wadden Sea. Helgol Mar Res 68(2):289-298

Southward AJ, Langmead O, Hardman-Mountford NJ, Aiken J, Boalch GT, Dando PR, Genner MJ, Joint I, Kendall MA, Halliday NC, Harris RP, Leaper R, Mieszkowska N, Pingree RD, Richardson AJ, Sims DW, Smith T, Walne AW, Hawkins SJ (2005) Long-term oceanographic and ecological research in the western English Channel. In: Southward AJ, Tyler PA, Young CM, Fuiman LA (eds) Advances in marine biology, (Vol 47). pp 1-105

Stachowicz JJ, Bruno JF, Duffy JE (2007) Understanding the effects of marine biodiversity on communities and ecosystems. Ann Rev Ecol Evol Syst 38:739-766

Tillin HM, Hiddink JG, Jennings S, Kaiser MJ (2006) Chronic bottom trawling alters the functional composition of benthic invertebrate communities on a sea-basin scale. Mar Ecol Prog Ser 318:31-45

Wang JP (2011) SPECIES: an R package for species richness estimation. J Stat Softw 40(9):1-15

Wood SN (2006) Generalized additive models: an introduction with R. Chapman and Hall/CRC, Boca Raton

Worm B, Barbier EB, Beaumont N, Duffy JE, Folke C, Halpern BS, Jackson JBC, Lotze HK, Micheli F, Palumbi SR, Sala E, Selkoe KA, Stachowicz JJ, Watson R (2006) Impacts of biodiversity loss on ocean ecosystem services. Science 314(5800):787-790

Zuur AF, Latuhihin MJ, Ieno EN, Baretta-Bekker JG, Smith GM, Walker NJ (2009) Additive mixed modelling applied on phytoplankton time series data. In: Zuur AF, Ieno EN, Walker N, Saveliev AA, Smith GM (eds) Mixed effects models and extensions in ecology with R. Springer New York, pp 423-446 